\title{
Teacher PAI Learning Strategy in Improving Self Control Students in Binjai State 4 High School
}

\author{
Mohd. Najmi Adlani Siregar ${ }^{1}$, Mesiono $^{2}$, Salamuddin ${ }^{3}$ \\ ${ }^{1}$ Postgraduate Program in Faculty of Tarbiyah and Teacher Training, Universitas Islam Negeri \\ Sumatera Utara, Indonesia \\ ${ }^{2,3}$ Faculty of Tarbiyah and Teacher Training, Universitas Islam Negeri Sumatera Utara, Indonesia \\ Email: Nazmiadlan.28@gmail.com
}

\begin{abstract}
This study aims to determine the learning strategies of Islamic Religious Education teachers in improving student self control in SMA Negeri 4 Binjai. To answer the research problem, researchers describe how the learning strategies of Islamic Religious Education teachers in improving student self control, and what are the inhibiting and supporting factors for implementing Islamic religious education learning strategies in improving student self control in SMA Negeri 4 Binjai. This study uses a qualitative method with the type of case study research so that this research problem can be explored in detail. Data collection techniques used were interviews, observation, and study of documents. The technique of guaranteeing the validity of the data is carried out by testing the data credibility, the dependability test, and the confirmation. Data analysis techniques used are data collection, data reduction, data presentation, and drawing conclusions. The result is PAI teacher learning strategies using several strategies including expository learning strategies, inquiry learning strategies, problem based learning strategies and cooperative learning strategies. In addition, the school has several strategies in improving student self control, namely the Individual approach to students, habit of doing positive things, organizing good programs and establishing joint responsibility to improve students' Self Control. Supporting and inhibiting factors in improving students' Self Control in SMA 4 Binjai In applying Self Control, there are several supporting factors. As the principal, teachers, staff and students provide good support and support all types of programs that are held. The inhibiting factor is that the infrastructure facilities are inadequate for learning given the large number of students who need conducive learning places. On the other hand learning time constraints become a barrier considering the lack of PAI learning hours which can only be used for the delivery of material demanded by the curriculum (syllabus) so that improvements in implementing self control cannot take place properly.
\end{abstract}

Keywords: learning strategies; PAI Teachers; self control

\section{Introduction}

Education is part of the intellectual life of the nation as mandated in the 1945 Constitution, likewise in the Law of the Republic of Indonesia No. 20 of 2003 concerning the National Education System which states that the goal of national education is to educate the life of the nation, to develop the potential of students so that they can become people who have faith and are devoted to God Almighty, noble, capable, creative, independent and become citizens of a democratic and responsible country. To that end, the government has sought to develop the education sector in a planned, directed, and gradual manner and integrated with the overall development of the nation's life, both economic, social, cultural, scientific and technological. (Rasien, 2020).

Students are ijtimaiah creatures, ijtimaiah beings are human beings who relate reciprocally with other humans, as ijtimaiah creatures they still need others to be able to grow 
and develop into humans who are intact in their development, their position and attitudes can change because they interact with each other and influence each other among students.

Islamic religious education is one of the coaching and training institutions provided for Islamic religious students with the aim that he has the knowledge and understanding to improve student self-control in order to be able to be human beings who believe and devote to Allah SWT, self-control (mujahadah al -nafs) is an earnest struggle or jihad against the ego or personal lust. This struggle is carried out because self-will leads to seeking various pleasures, paying attention to the rights that must be exercised, and neglecting obligations.

Self-control, self-control or self-control (self regulation) is an act, attitude or behavior of someone who is programmed consciously or unconsciously to comply with the values and social norms that apply in society wherever he is. Self-control is an important dimension in emotional intelligence (emotional quotient). This aspect is very important in human life because humanity's greatest enemy is not outside of himself, but rather within himself. Thus, wherever someone goes, then that person is always followed by "enemies" that exist in him.

Self Control is one of the abilities that must be possessed by Students, with a good Self Control in themselves, student behavior will be more directed towards a positive direction, but this ability does not necessarily form just like that, but must go through processes in life, including in dealing with conditions that exist in the surrounding environment. If a teacher is able to instill a good Self Control to their students, of course this will greatly facilitate the teacher in carrying out teaching and learning activities at school, besides that students will also be more respectful of themselves and others. In matching the increasingly sophisticated world changes, every individual (including adolescents) has a mechanism that can help regulate, control and direct their behavior or what is called self control.

Teacher's expertise in carrying out educational tasks is obtained after taking certain teacher education that is not possessed by other professions. There are several roles teachers can play as educators, including: (a) As a professional worker with the function of teaching, guiding and training. (b) Humanitarian workers with the function can realize all their human capabilities. (c) As a benefit officer with the function of teaching and educating the public to be good citizens (Saragih and Mardianto, 2019).

Self control is also one of the abilities that can be improved and used by individuals during the process of life which in dealing with certain conditions contained in the surrounding environment, self control can be used as an intervention that is preventive in addition to reducing the negative psychological effects of the situation which is full of pressure in the surrounding environment.

Self control is very important to be owned by everyone, because the entry of a foreign culture then changes in one's culture and lifestyle, due to the impact of globalization requires someone to behave and place themselves according to their presence in the midst of others with a variety of existing cultures. As one of the personality traits, self control in one individual with another individual is certainly very different. There are individuals who have low self control and there are individuals who have high self control. One of the effects of low individual self control is the occurrence of juvenile delinquency.

The selection of SMA 4 Binjai as the object of research, which caught the attention of the writer is the religious nuances that exist at SMA 4 Binjai. The author is both amazed and 
amazed, how can public (State) schools, which have no religious background but existing religious activities are not far behind boarding schools or schools with religious backgrounds or schools that are labeled Integrated Islamic Schools (IT), which has a lot of diversity activities, including praying Dhuha in congregation, praying dzuhur in congregation, reading the Qur'an together before the lesson begins, memorizing the Qur'an at Juz 30, muhadarah on every Tuesday after finishing the learning hours and there are also annual activities such as pondok romadhon and commemoration of Islamic holidays. Whereas Islamic Education in SMA 4 Binjai is no different from public schools in general, which is only limited to 3 hours of study a week. The material is an integrated unit of worship material, qurans, morals, history of Islamic culture which is wrapped into one subject, namely Islamic Education and Characteristics.

In connection with the above is proven by all Muslim women who wear the hijab, the dhuha prayer activities that run in an orderly manner, the activities of reading the Qur'an before learning, the midday prayer activities in congregation and other religious activities so that they have good commendable qualities that can be seen from day-to-day behavior, such as when among schools, attitudes when meeting teachers, greeting and greeting teachers even with their friends, obeying school rules, respecting and obeying parents and teachers, maintaining good manners, not withdrawing during class time, not praying rah and cluster and others can all be seen from the school environment. It crossed my mind, this is a public school with a nuance of madrasa. This is the background of the writer's desire to find out more, how the learning strategies of PAI teachers in improving self-control of their students, so that students carry out religious ritual activities and commendable behavior based on the awareness and willingness of their students, is not a coercion from the students the teacher, with Islamic Education subjects and existing religious activities, all who are in it have an Islamic religious spirit so that by themselves self control of all students in SMA 4 Binjai is well embedded especially in all students who are Muslim without exception.

The situation that occurred in SMA 4 Binjai seemed to be inversely proportional because a small portion of the students still behaved disgracefully, underestimated the rules and discipline of the school, late to school, pulled out at class time, liked to pretend and flocked, lacked hygiene, lacked hygiene, dressing modestly, dating, bullying his colleagues, talking impolitely to people who are older than him, making noise in class during class time even though the teacher is in class, unable to read the Qur'an and do not know the prayer reading recitation, and obey school rules for fear of punishment. What is wrong with them and what will be done by the teaching and educational staff of SMA 4 Binjai in responding to this case.

\section{Review of Literature}

The term strategy comes from the Greek Strategia which is interpreted as 'the art of the general' or the art of a commander normally used in warfare. Karl von clausewits argues that the notion of strategy is knowledge of the use of battles to win wars. In this modern age, users of the term strategy are no longer limited to the concept or art of a commander in warfare, but have been widely used in almost all fields of science. In a general sense, strategy is a way to win or achieve goals.

Related to understanding the I.L. strategy Pasaribu and B. Simandjuntak (1983: 76) explained: Strategy has an understanding as an outline of the direction in acting to achieve predetermined goals. Associated with teaching and learning, strategy can be interpreted as a 
general pattern of teacher-student activities in the realization of teaching and learning activities to achieve the goals outlined.

Martinis Yamin and Maisah (2009: 135) explain: In the world of education, strategy is defined as a plan, method, or series of activities designed to achieve a particular educational goal. Thus, the learning strategy can be interpreted as a plan that contains a series of activities designed to achieve educational goals.

From the above understanding. First, the learning strategy is an action plan (series of activities) including the use of methods and the use of various resources / strengths in learning. This means that the preparation of a new strategy until the process of preparing a work plan has not yet reached the action. The two strategies are arranged to achieve certain goals. That is, the direction of all strategy-making decisions is the achievement of objectives. Thus, the preparation of learning steps, the use of various facilities and learning resources are all directed towards the achievement of goals. Therefore, before determining the strategy, it is necessary to formulate clear goals that can be measured for success, because the goal is the spirit in the implementation of a strategy.

Islamic Religious Education Teachers are people who have professionalism in Islamic education personnel who are responsible for providing knowledge, guidance, and assistance to students in developing their maturity both in the cognitive, affective and psychomotor domains in accordance with the teachings of the Islamic religion, namely obeying Allah Almighty and His Apostles as well as stay away from anything that is forbidden by his religion.

Abuddin Nata (2001: 41) explains: In Arabic, the teacher is mentioned in terms of al'lim or al-Mu'allim (people who know), al-Mudarris (people who teach or people who give lessons) and al-Muaddib (which refers to teachers who specifically teach in the palace), and alUstâdz (to refer to teachers who teach the field of Islamic knowledge, and this designation is only used by the people of Indonesia and Malaysia).

From the above definitions, one definition can be drawn that the teacher is the main axis of education as an educator and teacher. Educate students to have knowledge and skills in each subject area. Besides the teacher also has the responsibility in educating students to have good attitudes and behavior, when in the school or community environment. If so it is said to be a teacher, the religious teacher (PAI) educates students by instilling Islamic values on cognitive, affective, and psychomotor in order to form Islamic personality in students.

Self-control is an individual's ability in sensitivity to read the situation themselves and their environment and the ability to control and manage behavioral factors in accordance with the situation and conditions to present themselves in socializing the ability to control behavior, the tendency to attract attention, the desire to change behavior to fit for others, pleasing others, without closing their feelings.

Associated with the notion of self control According to Confucius in Gunarsa (2004: 254-256) explains self control (self control) is the quality of self (self-sufficiency) and selfregulation (self-regulation). While self regulation is the ability of individuals to resist impulses and the ability of individuals to control their behavior when there is no control from the environment. Good self-regulation is a criterion of good self control too. 
Meanwhile in the Complete Psychology Dictionary of self control in his book Kartini Kartono (1999: 38) is defined as the ability of individuals to guide their own behavior; the ability to suppress or obstruct oneself from impulses or impulsive behavior.

Associated with the understanding of self control N. Ubaedi (2005: 169) explains: Self control is a mental activity to master what we think, what we feel, what we believe and what we do. Self control is an individual's skill in the sensitivity of one's own situation and environment and the ability to control and manage behavioral factors in accordance with the situation and conditions to present themselves in socializing.

Regarding the definition above, it can be concluded that self control is a mental and cultural value that is very important for the formation of other personalities and behaviors. The formation of good behavior, positive and productive, harmonious relationships with others is also influenced by the ability to control themselves. Proper study habits, discipline, orderly behavior in schools and in the community, healthy sexual behavior, and the formation of life habits are influenced by the ability to control themselves (self control). Meanwhile, deviant behavior, delinquency, promiscuity and failure of one's life are much influenced by low self control.

The formation of self control is influenced by several factors, namely internal (internal) and external (environmental) factors in which there are parenting styles, cultural values, and religious values so that each person will have a different level of self control, according to the level of education and development the environment in which he lives.

\section{Research Methods}

This study uses a qualitative method with the type of case study research so that this research problem can be explored in detail. Data collection techniques used were interviews, observation, and study of documents. The technique of guaranteeing the validity of the data is carried out by testing the data credibility, the dependability test, and the confirmation. Data analysis techniques used are data collection, data reduction, data presentation, and drawing conclusions.

\section{Discussion}

In the world of education all know that the task of religious teachers is not just teaching and giving knowledge to students but more than that namely improving students' Self Control so as to achieve a personality that can control themselves well so that students in doing things everything can be considered with well. To be able to realize students who can control themselves well, Islamic religious education teachers must have a strategy to improve Self Control because using strategies can produce desired goals in the world of education.

The types of learning strategies used by Islamic religious education teachers in SMA 4 Binjai are: The first, expository learning strategy, in implementing this strategy Islamic religious education teachers deliver material to students using lecture and demonstration methods or practice. Secondly, inquiry learning strategies, namely, the teacher gives assignments to students both in the form of memorization and writing, individual and group assignments. After that, the assignments were also discussed in the class once in a while so the 
participants did more fieldwork. Third, problem solving learning strategies, namely the teacher gives the opportunity to students to prepare what must be discussed and then the teacher directs students to be able to solve problems systematically and logically. The fourth, cooperative learning strategies, is a learning model that prioritizes cooperation between students, namely the teacher groups students in doing tasks, so that students can work together with their friends so that there is a closer bond between fellow students.

The other strategies used by teachers to improve students' Self Control at SMA 4 Binjai include:

a. Individual approach to High School 4 Binjai students who are rising adolescents tend to be more open and more receptive to advice if done personally. This approach is carried out by the method of dialogue between the teacher and students, dialogue is carried out in a relaxed and relaxed manner so that students will be directed to better understand.

b. Familiarize doing activities in a positive direction, ie at first good habituation needs to be forced. When students are accustomed to doing good things and are embedded in their souls, they will do the good deeds themselves without thinking about it first.

c. The establishment of shared responsibilities, this method is needed to ensure the presence of school community together. It is very difficult to change or make new habits towards an institution, especially educational institutions without a shared commitment.

d. Organizing a good program, namely the organization of the process of fostering Self Control of students in an institution requires a definite and clear program to achieve common goals namely students who can improve Self Control well.

In connection with the learning strategies implemented by Islamic religious education teachers in SMA 4 Binjai on improving students' Self Control, it is already very good, bearing in mind that by applying the learning strategies of incuri, expository, problem solving and cooperative, the implementation of the learning strategies above has a significant influence Significant to the increase in Self Control of students in SMA 4 Binjai, for example there are students who used to rarely perform prayers, with strategies undertaken by Islamic religious education teachers these students have begun to diligently worship for example dhuha prayers, midday prayers, although there are still also students who are usually not compliant with school rules. Students in SMA 4 Binjai are accustomed to carrying out religious matters, for example: performing midday prayers in congregation, reading the Qur'an before starting the PAI Material, and praying duha and memorizing the Qur'an. Students are accustomed to discipline, not fighting, not skipping class hours, studying independently, leaving for school on time. In addition, students are always trained or taught to be leaders through school organizations, so every year there is a change in the leadership of the organization.

In applying self control that there are several supporting factors. Such as: the principal gives full permission and support to the activity and facilitates the activity. The teachers at SMA Negeri 4 Binjai provide good support and support all types of programs that are carried out. In addition, the parents of students and the surrounding community provide good support and support all types of programs that are held and provide information in controlling students. This is done to make the program run well. 
All types of programs that have been made in enhancing student self control, habituation of positive things that have been built up so far in the school environment, as far as possible are maintained and developed into a habitat for students from generation to generation fully supported by the school (principals, teachers and staff) or other parties so that SMA 4 Binjai is not only a leader in the quality of learning, but also in terms of ethics, morals and religion. More serious attention and rewards for religious activities and coordination between PAI teachers and students will in addition strengthen the motivation of students to explore, live and love and practice their religious teachings holistically, while at the same time forming a creative, quality Muslim personality in the future. The positive example of spiritualism from PAI teachers and also all Muslim teachers and even especially from school leaders, needs to be encouraged again, especially in conducting prayers as a reflection of high religiousity in an educator. Because this exemplary factor becomes very effective carried out by all elements of the school in order to achieve the vision and mission in a proportional and balanced way between mastering information technology-based science and preparing the next generation who have faith, piety, and virtuous character.

In addition to supporting factors that there are inhibiting factors in implementing self control, there are several inhibiting factors for the implementation of Islamic religious education learning strategies in enhancing student self control in SMA 4 Binjai that facilities and infrastructure are inadequate, because facilities and infrastructure are very important in the learning process, but does not rule out the possibility of the principal's policy of facilitating class shortages only during religious education hours and initiating Muslim students to study at the mushallah so that students who are Muslim can carry out religious activities.

On the other hand, time limitation learning becomes an obstacle in implementing self control in SMA 4 Binjai. Like the lack of PAI learning hours which can only be used for the delivery of material demanded by the curriculum (syllabus) so that improvement and implementing self control cannot take place properly.

\section{Conclusions}

Islamic religious education teacher learning strategies in improving student self control in SMA 4 Binjai in the teaching and learning process using several strategies including expository learning strategies, inquiry learning strategies, problem-based learning strategies and cooperative learning strategies. In addition, the school has several strategies in improving student self control, namely the Individual approach to students, habituation to do positive things, good program organization and the formation of shared responsibilities in terms of improving students' Self Control. From the results of religious education carried out together this forms knowledge, attitudes, controls behavior in a positive direction, and good and true religious experience. Students will have noble character, honest behavior, discipline, and religious zeal to improve their quality.

Supporting and inhibiting factors in improving students' Self Control at SMA Negeri 4 Binjai In applying Self Control, there are several supporting factors. Like the principal, teachers and students provide good support and support all types of programs that are held. The inhibiting factor is that the infrastructure facilities are inadequate for learning given the large number of students who need conducive learning places. On the other hand learning time constraints become a barrier considering the lack of PAI learning hours which can only 
be used for the delivery of material demanded by the curriculum (syllabus) so that improvements in implementing self control cannot take place properly.

Suggestions that can be delivered related to the learning strategies of PAI teachers in improving students' self control in SMA Negeri 4 Binjai. The school should increase positive activities which are coordinated by the Trustees or PAI teachers. So that the number of activities at school teachers have a lot of time to control the activities of students at school, so that their activities are controlled and should Islamic religious education teachers always look for the best strategies for learning Islamic religious education, so that students' self control improvement can be better and more effective.

\section{References}

Ananda Rusydi. 2019. Perencanaan Pembelajaran. Medan: LPPPI.

D. Gunarsa. 2004. Singgih, Bunga Rampai Psikologi Perkembangan; Dari Anak Sampai Usia Lanjut. Jakarta: Gunung Mulia

Kartono. Kartini. 1999. Kamus Lengkap Psikologi. Jakarta: Raja Grafindo Persada.

Pasaribu. I.L. dan Simandjuntak. B. 1983. Proses Belajar Mengajar, Edisi II Bandung: Tarsito Bandung.

Nata, Abudin. 2010. IlmuPendidikan Islam. Jakarta: Kencana Prenada Media Group.

Rasien. 2020. The Effect of Blended Learning Strategy and Creative Thinking of Students on the Results of Learning Information and Communication Technology by Controlling Prior Knowledge. Budapest International Research and Critics in Linguistics and Education (BirLE) Journal. P. 879-893.

Saragih, K., and Mardianto. 019. Relationship between Teacher Professional Performance and Discipline of Workers withTeacher Professionalism in Madrasah Tsanawiyah in Pematangsiantar City. Britain International of Linguistics, Arts and Education (BIoLAE) Journal; 1(2): 77-84.

Ubaedi. N. 2005. 5 Jurus Menggapai Hidayah. Jakarta: Pustaka Qalami.

Yamin. Martinis and Maisah. 2009. Manajemen Pembelajaran Kleas : Meningkatkan Mutu Pembelajaran. Jakarta: GP Press. 